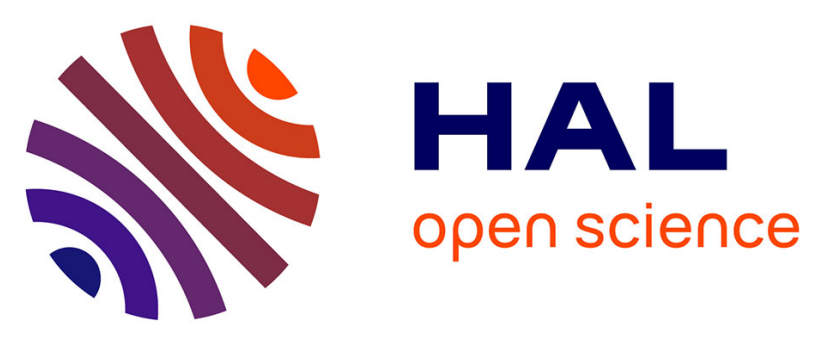

\title{
Vessels with Gold or Guilt: Emotional Reactions to Family Involvement Associated with Glorious or Gloomy Aspects of the Colonial Past
}

Sven Zebel, Sjoerd F. Pennekamp, Martijn van Zomeren, Bertjan Doosje, Gerben A. van Kleef, Michael L. W. Vliek, Job van Der Schalk

\section{To cite this version:}

Sven Zebel, Sjoerd F. Pennekamp, Martijn van Zomeren, Bertjan Doosje, Gerben A. van Kleef, et al.. Vessels with Gold or Guilt: Emotional Reactions to Family Involvement Associated with Glorious or Gloomy Aspects of the Colonial Past. Group Processes and Intergroup Relations, 2007, 10 (1), pp.71-86. 10.1177/1368430207071342 . hal-00571640

\author{
HAL Id: hal-00571640 \\ https://hal.science/hal-00571640
}

Submitted on 1 Mar 2011

HAL is a multi-disciplinary open access archive for the deposit and dissemination of scientific research documents, whether they are published or not. The documents may come from teaching and research institutions in France or abroad, or from public or private research centers.
L'archive ouverte pluridisciplinaire HAL, est destinée au dépôt et à la diffusion de documents scientifiques de niveau recherche, publiés ou non, émanant des établissements d'enseignement et de recherche français ou étrangers, des laboratoires publics ou privés. 


\title{
Vessels with Gold or Guilt: Emotional Reactions to Family Involvement Associated with Glorious or Gloomy Aspects of the Colonial Past
}

\author{
Sven Zebel, Sjoerd F. Pennekamp, Martijn van Zomeren, Bertjan Doosje, \\ Gerben A. van Kleef, Michael L. W. Vliek and Job van der Schalk \\ University of Amsterdam
}

\begin{abstract}
In two studies we examined whether forging a psychological bond with a nation's colonization past facilitates the experience of positive and negative group-based self-conscious emotions as a function of a positive or negative manipulation of this past. Because people need to belong, we hypothesized that stronger family involvement in a nation's colonization past (i.e. involved ancestors) evokes stronger a positive self-conscious emotions after positive descriptions of the nation's colonizing past, and stronger negative self-conscious emotions after negative descriptions. In Study 1, we found support for these hypotheses in a real-life setting in which Dutch people actually found out whether their ancestors were involved in the colonization of Indonesia or not. In Study 2, we manipulated family involvement and valence of the past. Results offered support for the tested hypotheses. Implications of the results are discussed in relation to theories on identity and emotion.
\end{abstract}

KEYWORDS emotions, family, involvement, past, valence

For most nations with a history of overseas colonization, there are two sides to the story. On the one hand, there are glorious aspects: the colonizing nations have often flourished economically, as well as culturally. On the other hand, there are gloomy aspects: this economic and cultural wealth has accumulated partly as a result of dominating people from the colonized country. Acknowledging particularly the gloom of the past is important for contemporary intergroup relations between the former colonizers and colonized nations as it may facilitate a desire to repair the wrongdoings of the past (Doosje, Branscombe, Spears, \& Manstead, 1998). However, particularly in cases where the colonization era lies in the (psychologically) distant past, people may be less likely to feel

\footnotetext{
$\overline{\text { Author's note }}$

Address correspondence to Sven Zebel, Department of Social Psychology, University of Amsterdam, Roetersstraat 15, 1018 WB Amsterdam, The Netherlands [email: s.zebel@uva.nl]
} 
psychologically connected to it, and are hence less likely to feel responsible for the wrongs committed. Rather, people are likely to distance themselves psychologically from the gloom of the past as they typically do with negative reflections of group membership (e.g. Cialdini et al., 1976; Snyder, Lassegard, \& Ford, 1986; Tajfel, 1978).

However, forging a psychological bond with the past may counter this general tendency. One way people may be linked with the past is through their family involvement: if my ancestors had been part of the Dutch colonizing force that dominated Indonesia for centuries, I would probably feel more implicated than if my ancestors had not been part of that group. Thus, family involvement may be a crucial link between the past and the present that moves people to acknowledge (particularly the gloomy aspects of) the nation's colonization past. In two experiments we therefore investigated the emotional reactions of people from a former colonizing country to the glorious or gloomy aspects of their seafaring nation's colonization past (the 'vessels with gold or guilt'), while they were informed about their family involvement in this past through an actual website (Study 1), or through bogus information (Study 2).

\section{Linking the past to the present}

People are social beings that have a fundamental need to belong (Baumeister \& Leary, 1995). As a consequence, most people belong to one or more groups such as being part of a nation, or a family. According to social identity theory (Tajfel \& Turner, 1979, 1986) people derive a part of their sense of self from such group memberships, and are motivated to maintain positive social identities (see also Tajfel, 1978). People thus derive part of their self-worth or esteem from these group memberships by comparing their own group with other groups (e.g. Luhtanen \& Crocker, 1992). For example, when one's soccer team has beaten their main rival, the next day one may walk around wearing the team's colors. In such situations people are likely to talk about the fact that 'we have won', but easily cut off less positive reflections of group membership after defeat by talking about how 'they have lost' (Cialdini et al., 1976). Thus, the valence of a particular group membership or social identity reflects directly on the self, termed 'basking in reflected glory' when people take on board the positive aspects of their group affiliation, and 'cutting off reflected failure' when people dissociate themselves from the negative aspects of their group affiliation (Cialdini et al., 1976; Snyder et al., 1986). The positive or negative reflection of a nation's colonization past thus could influence whether people include this past in the present.

However, when the colonization era lies in the distant past, current group members often know little about it and are unlikely to feel psychologically connected to it. As a consequence, people are likely to include such group memberships in the self only when it reflects positively on them (i.e. basking in reflected glory). More gloomy aspects of a nation's colonization past, however, are easily excluded from the self. Here we suggest that making salient family involvement in the distant past elicits a categorization which encompasses the past actors and their negative actions in one's family, making it difficult for individuals to exclude such negative information from the self (see also Dumont, Yzerbyt, Wigboldus, \& Gordijn, 2003; Gordijn, Wigboldus, \& Yzerbyt, 2001). Little theory and research, however, has devoted attention to the family as an important social identity. Nonetheless, one of the few studies that have investigated the role of the family on social identity concerns is a study by Mullen, Migdal, and Rozell (2003). In this study participants looked at a family tree while completing measures of ethnic identification. Results showed that being aware of one's descent heightens (in this case) ethnic identification. Thus, providing people with information about family involvement in the nation's colonization past may psychologically connect people with the nation's colonization past and hence increase its self-relevance. In other words, the past may become more meaningful and important to people when they feel involved 
(Pennekamp, Doosje, Zebel, \& Fischer, 2007). We therefore propose that people's sense of family involvement in the nation's colonization past is a key psychological bond that highlights the self-relevance of the past through another psychological channel than national identity (i.e. 'My ancestors sailed on vessels of gold'). Providing people with information about family involvement in the nation's colonization past may therefore lead people to include even the more negative aspects of this past in the social 'family' self.

We argue that family involvement may lead people to self-categorize as a member of a group that has done something positive or negative in the past. As such, it is related to the first antecedent of group-based emotions such as collective guilt, as specified by Branscombe, Doosje, and McGarty (2002). Ingroup identification, in contrast, is in most cases negatively related to the experience of collective guilt, because highly identified group members are less likely to accept unfavorable information about their group as valid (Doosje et al., 1998).

\section{Experiencing the past in the present}

The major implication of this line of thought is that people will differentially experience the past in the present as a function of the valence of the past and family involvement. As such this research extends insights from intergroup emotions theory (Mackie \& Smith, 2002; Smith, 1993) by proposing that family involvement facilitates the experience of positive and negative emotions based in this family group membership. Thus, when appraising the nation's colonizing past as glorious, people are likely to connect this glory to their family and experience positive group-based emotions when their family was involved. In contrast, when appraising the nation's colonizing past as gloomy, people are less likely to experience negative group-based emotions unless their family was involved. In line with these ideas, previous (mostly qualitative) research has shown that people are able to experience emotions as a group member, based on the past behavior of fellow family members (see e.g. Bar-On, 1990; Danieli, 1998).

Intergroup emotions theory (Smith, 1993) specifies which positive and negative group-based emotions are likely experienced as a function of group-based appraisals of the social context (see also Dumont et al., 2003; Gordijn, et al., 2001; Mackie, Devos, \& Smith, 2000; Mackie \& Smith, 2002; Yzerbyt, Dumont, Wigboldus, \& Gordijn, 2003). Based in general appraisal theories of emotion (for an overview see Scherer, Schorr, \& Johnstone, 2001), intergroup emotions theory postulates that positive versus negative groupbased emotions result when people appraise a situation as facilitating versus hindering the goals, needs or concerns of their group. In addition, other more differentiated appraisals determine which particular positive or negative emotion is elicited. For example, group-based anger is evoked when people appraise that (members of) their group have been harmed, and appraise others to be responsible for this injustice (e.g. Yzerbyt et al., 2003).

In the present research, we argue that the evaluative nature of the group-based emotions (positive versus negative) that are experienced depend on the valence of the colonization past. Most importantly however, information about one's family involvement in this past may serve as an appraisal of social self-awareness, because it makes people aware of the past actions of their family. Therefore, learning that family members were involved in the nation's glorious colonization past may induce positive self-conscious emotions such as pride about the past accomplishments of one's family (see also Lewis, 2000; Tracy \& Robins, 2004). Such positive self-conscious emotions should co-occur with a 'boost' in the self-esteem one derives from one's family. In a similar vein, awareness of one's family involvement in the nation's gloomy past may induce negative selfconscious emotions such as shame and guilt about the past harm that one's family has inflicted (see also Doosje et al., 1998; Lickel, Schmader, Curtis, Scarnier, \& Ames, 2005; Tangney \& Dearing, 2002). Accordingly, self-esteem as it is related to one's family should drop. We 
examine these emotions in Studies 1 and 2 and expect that forging a link between the past and the present may be crucial to allow people to experience such self-conscious emotions.

\section{Hypotheses}

More specifically, we expect that for those people whose family was strongly involved in the Dutch colonization era, more positive self-conscious emotions such as pride and contentment are experienced after a favorable description of this colonization, and more negative self-conscious emotions such as shame and guilt after a negative description (H.1a). In contrast, for people whose family was not involved in the Dutch colonization of Indonesia, the experience of positive and negative self-conscious emotions should not differ as much after a positive or negative portrayal of this era (H.1b). In statistical terms these predictions constitute a three-way interaction between valence, family involvement and emotion type.

\section{Study 1}

In Study 1 we tested our main assumption of the current research. That is, we assume that young Dutch people often do not know much about their family involvement in their nation's colonizing past, but that informing them of the possibility of descending from a person actively engaged in the colonizing past would strengthen the link with the past and make this past more personally relevant. To examine this assumption we used a website (http://voc.websilon.nl) that allows people to search a database for possible ancestors that sailed on Dutch 'vessels of gold' to conduct a first study.

\section{Method}

Sample Participants were 150 students from a large university in the Netherlands. We deleted the data from participants who had indicated that both of their parents were not born in the Netherlands.

Design We employed a 2 by 2 factorial design: people were presented with either a positive or a negative description of their nation's past colonization of Indonesia (Valence: Positive versus Negative), and subsequently found out that their direct ancestors either were or were not involved in the colonization of Indonesia (Family Involvement: High versus Low).

Procedure Participants were presented with a description of the colonization of Indonesia and the 'VOC' (i.e. the United East Indian Company, the former Dutch trade company through which Indonesia was colonized). The description first consisted of an introduction about the organization and trade network that the VOC developed in Indonesia from the year 1602 onwards, as a result of which Indonesia became a Dutch colony. Next, in the positive condition, positive consequences of this colonization were made salient (e.g. the Dutch did well economically due to this colonization, and this has contributed considerably to the current high level of prosperity in the Netherlands). In the negative condition, negative consequences were made salient (e.g. The Dutch exploited the Indonesians and their country, and this has influenced the current low level of prosperity in Indonesia). These descriptions were derived partly from stimulus material of Doosje and colleagues (1998).

Subsequently, we instructed participants to search a web-based database for their family name, which resulted in a number of 'hits'. This number of hits reflected the number of people on Dutch trading ships sharing their family name between 1700-1794, and hence provided a proxy for participants' link with the past through family involvement. Search results also included the first name(s) of the person sharing one's family name, this person's place of origin, the name of the vessel that this person sailed on, and the year of the vessel's departure. A maximum of 250 hits were shown by the website, with a maximum of 10 hits shown at each page. We asked our participants to search the database and subsequently fill out a brief questionnaire.

Dependent variables In order to check our manipulation of valence of history of colonization, we 
asked for their overall impression of the VOC and the consequences of the colonization (from -3 to +3$)$. We checked the family involvement by asking the participants to indicate how likely it is that their ancestors were involved in the colonization of Indonesia, in terms of a percentage (from 0 to $100 \%$ ). We assessed positive self-conscious emotions with two items: how proud and content they felt about these results $(r=.43, p<.001)$ (alpha is .60$)$, and negative self-conscious emotions as well with two items: how much shame and guilt they felt about these results $(r=.55, p<.001)$ (alpha is .70). We also checked if the manipulations influenced the perception of the self-relevance of the past: 'How relevant is the colonial past for you personally?' These emotion and self-relevance items were all answered on scales ranging from 0 (not at all) to 6 (very much).

\section{Results}

All reported analyses of variance (ANOVAs) consisted of two between-subject variables: Valence (Positive vs. Negative) and Family Involvement (High vs. Low).

Data inspection A considerably larger portion of our participants found hits than no hits (positive, high involvement condition, $n=59$; negative, high involvement condition, $n=54$; positive, low involvement condition, $n=16$; negative low involvement condition, $n=21)$. As Tabachnik and Fidell (2001, pp. 296-297) indicate, such unequal cell sizes produce a non-orthogonal design and tests for main effects and interaction effects are no longer independent in ANOVA. Tabachnik and Fidell suggest using Type I Sum of Squares as a remedy for this problem, particularly when the non-experimental nature of the research causes the unequal cell sizes. In this study this seems to be the case: we could not randomly assign people to the high or low family involvement condition, and the fact that a larger number of people found hits than no hits can be considered as informative about the occurrence of hits in the population. Type I Sum of Squares takes into account this differential occurrence of conditions by assign- ing heavier weights to the larger cells when computing marginal means and lower-order interactions. Therefore, following Tabachnik and Fidell's suggestions, we adjusted the ANOVAs in this study to Type I Sum of Squares.

Manipulation checks Participants' estimates of family involvement (in terms of a percentage) was influenced by whether they had found hits (suggesting possible family involvement; $M=27.80, S D=30.34$ ) or no hits (suggesting little family involvement; $M=7.25, S D=17.15$ ) $\left(F(1,146)=14.62, p<.001\right.$, partial $\eta^{2}=.091$, we refer to the partial $\eta^{2}$ that SPSS generates as $\eta^{2}$ ). Interestingly, an unexpected marginal effect of valence emerged $(F(1,146)=3.71$, $\left.p=.056, \eta^{2}=.025\right)$, indicating that participants estimated a lower chance of family involvement in the negative condition $(M=15.42, S D=25.89)$ compared to the positive condition ( $M=19.63$, $S D=31.44)$. The interaction effect was not significant, however $(F(1,146)=1.34, p=.25$, $\left.\eta^{2}=.009\right)$.

We tested the success of the valence manipulation with the question about participants' general impression of the VOC, and found the expected main effect of valence $(F(1,146)=16.24$, $\left.p<.001, \eta^{2}=.10\right)$, the means indicating a more positive view of the VOC and its consequences in the positive $(M=+0.41, S D=0.99$; a $t$ test shows that this is different from zero, $p<.0005)$ than negative condition $(M=-0.23, S D=1.40$; this mean tended to differ from zero, $p=.074$ ). No other effects emerged on this manipulation check (all $F \mathrm{~s}<1.68, p \mathrm{~s}>.19$ ). Thus, these analyses demon-strate that the naturally occurring information about family involvement on the website and our manipulation of valence of history of colonization were successful.

Self-conscious emotions Subsequently, we performed a GLM (using Type I Sum of Squares) including both independent variables (valence of condition and family involvement) with emotion type (positive versus negative self-conscious emotions) as a within-subjects factor. This analysis revealed a significant main effect of emotion type $\left(F(1,146)=114.98, p<.001, \eta^{2}=.44\right)$, showing that participants overall reported 
stronger positive self-conscious emotions $(M=2.25, S D=1.35)$ than negative self-conscious emotions $(M=0.93, S D=1.17)$. However, most importantly, this main effect was qualified by the predicted three-way interaction effect between valence, family involvement and emotion type $\left(F(1,146)=4.03, p=.047, \eta^{2}=.027\right)$.

To disentangle this three-way interaction and test our hypotheses regarding the influence of low versus high involvement, we examined the effects within these conditions. Supporting our prediction that the experience of selfconscious emotions would reflect the valence of the colonization description when family involvement was high, the simple interaction between emotion type and valence was significant in the high involvement condition $(F(1$, $146)=4.25, p=.041)$. This two-way interaction showed that positive self-conscious emotions were significantly stronger in the positive condition $(M=2.95 ; S D=1.26)$ compared to the negative condition $(M=2.31, S D=1.36)$ $(p=.009)$. However, unexpectedly, negative selfconscious emotions were equally strong in the negative condition $(M=1.06, S D=1.22)$ and the positive condition $(M=1.06, S D=1.12)(p=.98)$. In contrast, the simple interaction between emotion type and valence was not significant when family involvement was low $(F(1,146)=1.29$, $p=.26$ ), indicating that the experience of positive and negative self-conscious emotions was not influenced by the valence manipulation when participants' families were not involved in the colonization era (see Table 1).

Self-relevance of the past We also posed the question: 'To what extent did you find this past personally relevant?' Unexpectedly, people who found their name in the database did not reliably score higher on this variable $(M=1.92$, $S D=1.73)$ than people who did not find hits, although the means were in the right direction $(M=1.51, S D=1.55)(F(1,146)=2.24, p=.14$, $\left.\eta^{2}=.015\right)$. The main effect of valence did reach significance $(F(1,146)=5.65, p=.019$, $\left.\eta^{2}=.037\right)$. People considered the history more self-relevant in the positive condition $(M=2.19, S D=1.59)$ than in the negative condition $(M=1.25, S D=1.76)$. Interestingly, the interaction between family involvement and valence was significant $(F(1,146)=4.33$, $\left.p=.039, \eta^{2}=.029\right)$. Looking at the means, it can be seen that in the negative condition, people with no hits $(M=0.71, S D=1.15)$ scored lower on self-relevance of this past than people with hits $(M=1.78, S D=1.87$; simple main effect analysis $F(1,146)=6.29, p=.013)$. In the positive condition, the difference between the no hits condition $(M=2.31, S D=1.58)$ and the hits condition $(M=2.07, S D=1.60)$ was not significant $(F(1,146)<1)$ : they were both relatively high. As a consequence of these high means in the positive condition, the no hits positive condition was considered to be more

Table 1. Mean scores and standard deviations on main dependent variables, Study 1

\begin{tabular}{|c|c|c|c|c|}
\hline & \multicolumn{4}{|c|}{ Family involvement } \\
\hline & \multicolumn{2}{|c|}{ High } & \multicolumn{2}{|c|}{ Low } \\
\hline & $\begin{array}{l}\text { Positive } \\
\text { valence }\end{array}$ & $\begin{array}{l}\text { Negative } \\
\text { valence }\end{array}$ & $\begin{array}{l}\text { Positive } \\
\text { valence }\end{array}$ & $\begin{array}{c}\text { Negative } \\
\text { valence }\end{array}$ \\
\hline \multicolumn{5}{|c|}{ 1. Positive self-conscious emotions } \\
\hline$M$ & $2.95 \mathrm{a}$ & $2.31 b$ & $1.66 \mathrm{~b}$ & $2.07 \mathrm{~b}$ \\
\hline$S D$ & 1.12 & 1.34 & 1.14 & 1.32 \\
\hline \multicolumn{5}{|c|}{ 2. Negative self-conscious emotions } \\
\hline$M$ & $1.06 \mathrm{c}$ & $1.06 \mathrm{c}$ & $0.91 \mathrm{c}$ & $0.69 \mathrm{c}$ \\
\hline$S D$ & 1.12 & 1.22 & 1.59 & 0.99 \\
\hline
\end{tabular}

Note: Means that do not share the same subscript but at least share one level of an independent variable differ at $p<.01$. 
relevant than the no hits negative condition $(F(1,146)=8.54, p=.004)$. No other effects emerged on this measure.

\section{Discussion}

This first experiment gives us hints as to how people react in terms of self-conscious emotions to their nation's colonization past as a function of family involvement. We have to take care, however, when interpreting the results due to the large cell differences.

The checks of the naturally occurring differences in terms of family involvement and our manipulation of the valence of the history of colonization suggested a successful procedure. People indicated higher estimates of the chance of family involvement when their family name was mentioned in the database than when it was not. The other independent variable was manipulated, and results show that people generally had a more favorable perception of the Dutch sailors in the positive condition than in the negative condition.

The significant three-way interaction revealed that when family involvement was high, people experience different self-conscious emotions as a function of valence of the presented history, but not when family involvement was low. Specifically, when family involvement was high, people experience more positive emotions when presented with a positive version of the colonial history rather than a negative one.

Interestingly, self-relevance was higher when people received positive information about their group's past than when negative aspects were highlighted. Moreover, participants also indicated a slightly higher chance of family involvement after positive compared to negative information. These results are directly in line with the 'basking in reflected glory' effect (Cialdini et al., 1976; Snyder et al., 1986). People like to associate themselves with positive and successful others, be it a person or a group. The ideas by Tajfel (1978) that were explicitly tested by Ellemers (1993) also receive support: people feel more connected to a group when it has positive features rather than negative features. With respect to the self-relevance of the past, it is important to note that only when the link between the past and the present was made explicit through high family involvement did people perceive the negative information about the Dutch colonization of Indonesia as self-relevant. We argue that this is because social reality puts constraints on the possibilities to 'cut off reflected failure' (Cialdini et al., 1976). When faced with such explicit evidence, people have to acknowledge the self-relevance of this group's past, even if they prefer not to.

While this first experiment used a real-life setting, and as such has a high external validity, it may undermine the internal validity, i.e. the possibility of drawing causal inferences from this study (although we did manipulate the valence of the history, and this resulted in predicted patterns). Therefore, in the second study, we tested the same hypotheses using a manipulation of both valence and family involvement.

\section{Study 2}

Study 1 indicates in a real-life setting how awareness of family involvement in a historical episode can give rise to group-based self-conscious emotions as a function of the evaluative nature of this episode. Despite the merits of this setting in Study 1, it also contains a potential threat to the internal validity of the results. That is, we acknowledge that the 'number of hits' from the website used as an indicator of family involvement is ambiguous. For example, finding a lot of 'hits' does not constitute direct evidence that one had many ancestors (and hence strong family involvement), because, for instance, people may have family names that occur relatively often. With such ambiguity present, we cannot rule out the influence of alternative factors on participants' responses in Study 1 (i.e. emotions may have been elicited through the mere appearance of participants' family name in a positive or negative context, irrespective of family involvement).

In this respect it is important to note that the predicted pattern of results in terms of negative self-conscious emotions in Study 1 did emerge on feelings of shame, but not on guilt. ${ }^{1}$ First, an 
explanation for this might lie in the fact that participants estimated the chance of descending from the earlier Dutch people as slightly lower after a negative description of the colonization era than after a positive description, which may have weakened the elicitation of negative selfconscious emotions. Second, the ambiguity in the meaning of 'number of hits' may also offer an explanation. As Lickel and colleagues (2005) have argued, guilt more than shame depends on the control or involvement people have in a specific situation. If participants in Study 1 doubted whether they descended from the people displayed by the 'hits' on the screen (as their overall low estimates of their family involvement in terms of percentages seem to suggest), then they most likely were also unsure about whether their specific family was involved in the nation's gloomy past. As a consequence of this ambiguity about the involvement of their family, feelings of guilt may not have arisen, whereas feelings of shame may have been elicited because the family's name was sufficiently suggested to be tainted.

However, we do believe that family involvement is the process through which a link can be made between current people and people in the distant past. In our view, this linkage involves current people in the actions their ancestors have undertaken in the past, and as such not only increases the association with past ancestors, but also the responsibility for the consequences of these actions. As such, this link should give rise to negative (shame as well as guilt) self-conscious emotions when the ancestors' past actions have harmed others, and to positive self-conscious emotions when others fared well because of them. Therefore, we set out to manipulate the degree of family involvement in the past in Study 2 to demonstrate its causal role in eliciting these group-based self-conscious emotions.

In Study 1, we have used a manipulation of valence of history in which the focus was either on the positive consequences for the ingroup, or the negative consequences for the outgroup. While this may have led to a high external validity, in Study 2, we want to disentangle the valence and target of consequences, and therefore focus only on the positive or negative consequences of the past ingroup's behavior for the outgroup.
In terms of our hypotheses, we thus expected to replicate the three-way interaction obtained in Study 1 between valence, family involvement and emotion type. Aside from the items used in Study 1 to measure the self-conscious emotions (e.g. pride, contentment) we included additional items in Study 2 that should be associated with the positive self-conscious emotion of pride (i.e. happy, cheerful), as well as additional items for negative self-conscious emotions (i.e. regret, embarrassment). In this way, we administered a more elaborated measure of these emotions in Study 2. Furthermore, we also examined whether the manipulation of family involvement threatens or boosts participants' self-esteem derived from their family, depending on the evaluative nature of the collective past. Therefore, we adapted Luhtanen and Crocker's (1992) collective selfesteem scale to measure self-esteem associated with the family. Crocker and Luhtanen (1990) demonstrated that the private collective selfesteem subscale of this measure (i.e. the degree to which people personally think positively about their ingroup) was most strongly related to negative feedback about the ingroup. In line with these findings, we predicted that the private 'family' self-esteem subscale would be most congruent with participants' self-conscious emotional responses.

\section{Method}

Participants and design Altogether, 141 students (53 males, 88 females; mean age 20.8 years) participated in an experiment in exchange for required course credit or 7 euros. Deleted from the data were participants who had indicated that both of their parents were born in a country other than the Netherlands. Participants were randomly allocated to one of four experimental conditions, constituting a 2 (valence: positive vs. negative) $\times 2$ (family involvement: high vs. low) factorial design. ${ }^{2}$

Procedure Upon entering the lab participants were seated in a cubicle where they sat behind a computer screen to participate in the experiment. After doing several unrelated tasks, participants were introduced to the experiment. They read that the aim of this research was to examine to what extent the Dutch colonization past was still 
part of the present. Participants read that the researchers had managed to combine a database containing detailed archives from the VOC (i.e. the United East Indian Company) with a database of the Dutch register of population, and that, with participants " permission, these data could be combined to estimate participants' family-based link with their possible ancestors in the nation's colonization past. Ostensibly involved parties were the Ministry of Education, and a variety of Dutch universities. Participants were asked to answer questions about themselves and their relatives, as this information was necessary to link the person to the database (if they provided permission for the researchers to use their personal information). After signing a consent form that allowed the researchers to use participants' personal information, they were asked questions about their first name and surname, their date of birth and place of residence. Similar questions were asked for the mother, father, grandfathers and grandmothers of the participant. We also asked whether these relatives were at present dead or alive. Participants were instructed to answer 'Don't know' if they could not provide information with certainty. After having provided all this information, participants waited for the computer program to link their personal information with the VOC database and the Dutch register of population. In the mean time, they read a text about the VOC that was framed in a positive or a negative way. In the positive condition participants read that the VOC presence in Indonesia had been beneficial for the Indonesians (e.g. the Dutch improved the Indonesian infrastructure and helped to set up an educational system), whereas in the negative condition participants read that this presence had been harmful for the Indonesians (e.g. the Dutch exploited both the natural sources of Indonesia and the Indonesians). In this manner, the two conditions represent benefits or costs to the outgroup only (caused by the ingroup).

After the valence manipulation, participants received feedback in terms of the link between their personal information, the Dutch population register and the VOC database. First, participants received information about their family involvement in terms of the chance of descent.
In the high family involvement condition, participants read that results suggest a $92.3 \%$ chance that they were descendants of those working for the VOC, and that this was a big chance. In the low family involvement condition, they read that results suggested a $12.3 \%$ chance, which was a small chance. After having provided participants with this information, dependent measures followed. Finally, they signed a second consent form that allowed the researchers to use participants' responses to the dependent measures.

\section{Dependent Variables}

Manipulation checks We checked our valence manipulation by asking participants: 'What is your perception of the VOC and its consequences for the present?' on a scale ranging from 1 (very negative) to 7 (very positive). We checked our family involvement manipulation by asking participants: 'How big is the chance that you descend from those working for the VOC?' on a scale ranging from 1 (very small) to 5 (very big).

Positive self-conscious emotions To measure participants' positive self-conscious emotions as a result of the information presented, we used the same two items as in Study 1 (proud and content), and included two extra items (happy and cheerful). Together, these four items proved to be a reliable scale $(\alpha=.80)$. Answering possibilities ranged from 1 (not at all) to 7 (very much).

Negative self-conscious emotions We assessed negative self-conscious emotions with the same two items as in Study 1 (guilt and shame), together with three new items: ashamed, embarrassed and regret. These five items indicated excellent reliability when combined into a scale $(\alpha=.93){ }^{3}$

Collective self-esteem We used Luhtanen and Crocker's (1992) measure of collective selfesteem to examine the impact of the information presented on participants' self-esteem with respect to their family. Thus, we tailored each item in the scale to focus on family self-esteem (e.g. 'In general, I'm glad to be a member of 
the family I belong to'). The four subscales that Luhtanen and Crocker differentiated all indicated good reliabilities ( $\alpha$ ranging from $.77-.87)$. All emotions and self-esteem items were answered on scales ranging from 1 (strongly disagree) to 7 (strongly agree).

\section{Results}

All reported ANOVAs consisted of two between subject variables: Valence (Positive vs. Negative) and Family Involvement (High vs. Low).

Manipulation checks The expected main effect of valence on participants' perception of the VOC was significant $\left(F(1,137)=11.61, p=.001, \eta^{2}=\right.$ $.08)$, indicating a more positive view of the VOC and its consequences in the positive $(M=4.58$, $S D=1.31$; a $t$ test shows that this is different from the midpoint $4, p=.002$ ) than negative condition $(M=3.83, S D=1.34$; not different from scale midpoint, $p=.248$ ). In addition, the family involvement manipulation led participants in the low involvement condition to indicate a lower probability $(M=1.07, S D=0.30)$ that they descended from those working for the VOC than those in the high involvement condition $(M=4.83, S D=0.45) \quad(F(1,137)=3458.12$, $\left.p<.001, \eta^{2}=.96\right)$. These results indicate that the manipulations were successful. No other effects emerged on these checks.

Self-conscious emotions To analyze the emotions, we performed a similar ANOVA as in Study 1 with emotion type (positive versus negative selfconscious emotions) as a within-subjects factor. This analysis indicated a main effect of emotion type $\left(F(1,137)=295.11, p<.001, \eta^{2}=.68\right)$, such that participants overall reported stronger positive self-conscious emotions $(M=3.64$, $S D=0.96)$ than negative self-conscious emotions $(M=1.79, S D=1.04)$. In addition, a significant interaction emerged between emotion type and valence $\left(F(1,137)=8.45, p=.004, \eta^{2}=.06\right)$, indicating that in the negative description condition, participants experienced stronger negative self-conscious emotions $(M=2.01$; $S D=1.10)$ than in the positive description condition $(M=1.58 ; S D=0.94)(p=.007)$. However, the experience of positive self-conscious emotions did not differ as a function of the valence manipulation (negative description $M=3.56 ; S D=0.95$; positive description $M=3.72$; $S D=0.97)(p=.28)$.

However, most central to the present argument, these effects were qualified by the predicted threeway interaction effect between valence, family involvement and emotion type $(F(1,137)=5.64$, $p=.019, \eta^{2}=.04$ ) (see Table 2). Supporting our prediction that the experience of selfconscious emotions would reflect the valence of the colonization description when family involvement was high, the simple interaction between emotion type and valence was again significant in the high involvement condition $(F(1,137)=12.94, p<.001)$. As expected, this simple interaction indicated that negative selfconscious emotions were significantly stronger when participants had read a negative description ( $M=2.39 ; S D=1.21)$ compared to a positive description $(M=1.54, S D=0.91)(p=.001)$. In addition, positive self-conscious emotions were somewhat weaker when participants received a negative description $(M=3.77, S D=1.07)$ compared to a positive description $(M=4.07$, $S D=1.12)$, although not significantly so $(p=.20)$. In contrast, the simple interaction between emotion type and valence was not significant when family involvement was low $(F(1,137)<1$, $p=n s)$, indicating that the experience of positive and negative self-conscious emotions did not differ as a function of the valence manipulation when participants' families were weakly involved in the colonization era (see Table 2).

Collective self-esteem subscales: private collective self-esteem Analyses on the four subscales of the collective self-esteem measure (Luhtanen \& Crocker, 1992) showed that the predicted interaction between valence and family involvement showed a trend on the private collective self-esteem scale $(F(1$, 137) $\left.=2.81, p=.096, \eta^{2}=.022\right)$, but did not affect the other subscales $(F \mathrm{~s}(1,137)<1.80$, $p s=n s)$. Consistent with the pattern of results on participants' self-conscious emotions, this interaction indicated that participants' private collective self-esteem in the negative high family involvement condition $(M=5.70, S D=$ 1.13 ) was marginally significantly lower than in the positive high family involvement condition 
Table 2. Mean scores and standard deviations on main dependent variables, Study 2

\begin{tabular}{|c|c|c|c|c|}
\hline & \multicolumn{4}{|c|}{ Family involvement } \\
\hline & \multicolumn{2}{|c|}{ High } & \multicolumn{2}{|c|}{ Low } \\
\hline & $\begin{array}{l}\text { Positive } \\
\text { valence }\end{array}$ & $\begin{array}{l}\text { Negative } \\
\text { valence }\end{array}$ & $\begin{array}{l}\text { Positive } \\
\text { valence }\end{array}$ & $\begin{array}{c}\text { Negative } \\
\text { valence }\end{array}$ \\
\hline \multicolumn{5}{|c|}{ 1. Positive self-conscious emotions } \\
\hline$M$ & $4.07 \mathrm{a}$ & $3.77 \mathrm{ab}$ & $3.42 b$ & $3.38 \mathrm{ab}$ \\
\hline$S D$ & 1.12 & 1.07 & 0.70 & 0.80 \\
\hline \multicolumn{5}{|c|}{ 2. Negative self-conscious emotions } \\
\hline$M$ & $1.54 \mathrm{c}$ & $2.39 \mathrm{~d}$ & $1.61 \mathrm{c}$ & $1.68 c$ \\
\hline$S D$ & 0.91 & 1.21 & 0.98 & 0.89 \\
\hline
\end{tabular}

Note: Means that do not share the same subscript but at least share one level of an independent variable differ at $p<.01$.

$(M=6.14, S D=0.75)(F(1,137)=3.90, p=.053)$. No difference in private collective self-esteem emerged when family involvement was low (negative $M=5.92, S D=0.81$; positive $M=5.85$, $S D=0.87)$. No other effects emerged ${ }^{4}$

\section{Discussion}

Study 2 replicated and extended findings observed in Study 1 by manipulating both valence of the history and family involvement. Overall, we find clear support for a conceptual replication of the Study 1 results. Specifically, people experience more self-conscious emotions when they share group membership with others than when they do not. Thus, the simple interaction between type of emotion and valence was again only significant when family involvement was high, and not when it was low. Specific effects indicated that although people experience a similar degree of positive self-conscious emotions from group membership when the group is described as having a glorious past rather than a gloomy past, the means were in the right direction, and the same direction as in Study 1 (in line also with the 'BIRGing' proposition: Cialdini et al., 1976; Snyder et al., 1986). Thirdly, people experience more negative self-conscious emotions such as shame and guilt when they are led to believe that they are part of a group with a gloomy past. Apparently, when the involvement of one's family in a negative collective past is explicated, people are susceptible to taking on board its emotional implications. These negative self-conscious emotions can have a broad range of behavioral consequences that may help to acknowledge formerly neglected historical mistreatments of outgroups (e.g. Doosje et al., 1998; Swim \& Miller, 1999).

Study 2 also extends the findings of Study 1 by showing that private collective self-esteem may be influenced by family involvement in the past in a similar manner as self-conscious emotions. Thus, people tend to have a lower collective self-esteem when they believe they are members of a group with a gloomy past rather than a glorious past. When their family was not involved, people did not respond differently to a favorable versus an unfavorable account of their nation's colonial history. Thus, people's evaluation of their present family seems to be influenced by the historical information they received in combination with information about the involvement of their family in the nation's history. That is, people's personal image of their family tends to 'suffer' when they learn how their family was involved in the exploitation of others, while the same image may be boosted when they believe that their family has participated in great accomplishments. Not only does this finding offer insights into how we can make people aware of what happened in the distant past, it also shows how current people may actually become affected, even when this past is gloomy. As such, this research may give us clues as to how (positive as well as negative) historical episodes 
can become salient in the present and affect people's self-esteem. In sum, Study 2 clearly demonstrated how family involvement makes people aware of the role of their family in the nation's past, and as such gives rise to positive or negative self-conscious emotions depending on the valence of this past.

\section{General discussion}

In two studies, we focused on (negative and positive) self-conscious emotions based on the (manipulated) valence of people's nation's past and the role of their family in this past. In both studies, people's reported self-conscious emotions were affected by the manipulated valence of the history when people were under the impression that their family might have been involved in the colonial overseas past. When people found out (Study 1) or were told (Study 2) that the chances of family involvement were low, the presented valence of the colonial history did not make a difference.

In Study 1, the strongest positive self-conscious emotions were experienced when people were led to believe that their family was involved in a glorious past of the nation. In Study 2, we made the link between the family in the past and the participants in the present more explicit by manipulating this link. In this study, we replicated the findings from Study 1 with more elaborate measures of both negative and positive self-conscious emotions. Thus, in both studies the predicted three-way interaction was significant, and although not all specific effects were significant in both studies, generally speaking, it can be concluded that people are more likely to experience positive self-conscious emotions such as pride when their own family was involved in a glorious past of the nation. Similarly, people experience more negative self-conscious emotions such as shame when people believe that their own family has played a role in the gloomy past of the nation. What can we conclude from these studies?

First, both manipulations (i.e. valence of nation's history and family involvement) resulted in predictable patterns. This means that people's beliefs about the past of their nation are not written in stone, but malleable to some extent. As Barkan (2000, p. x preface) argues: 'We used to treat history as an "objective" knowledge of past events that were largely immune from reinterpretation. . . Increasingly, however, we recognize the growing elasticity of history and that it is anything but fixed'. It is not only historians that acknowledge the malleability of history, it is clear from this research that people's opinions about the past of their group is partly shaped by the valence of the information presented to them. The portrayal of their group's past in Indonesia influenced people's perception of their national group. In a similar vein, we were able to observe predictable patterns as a function of 'actual' (Study 1) or manipulated (Study 2) family involvement. In other words, people's knowledge about the history of their family did not hinder the success of our manipulation of family involvement in the colonial past. This may have been caused by the fact that the history of Indonesia lies in a relatively distant past, and that our sample consisted of relatively young people, who, on average tend to know less about the history of their nation and their family than older people. For example, research by Wolf (2005) shows that, in the Netherlands, younger people (age 18-25) know less than older people about the role of the Dutch UN soldiers in the genocide in Sebrenica in 1995.

'Our history shapes our identities' (Barkan, 2000 , p. x preface). This quote underlines the link between the history of a nation and its inhabitants. In a general sense, it is argued that people, to some extent, depend on their identity to be on their group membership(s) (e.g. Tajfel \& Turner, 1986). Indeed, when people are asked to answer multiple times to the question 'Who are you?', they are likely to refer to group memberships as a way to describe themselves. We argue that in terms of national groups, the history of a nation is shaping both the content and evaluative nature of part of the social identities of people. How?

People generally both have and aim to achieve a positive sense of the self (Tajfel \& Turner, 1986). In other words, people like to feel good about themselves, at the individual level of the self, 
and at the group membership level of the self. Thus, people generally perceive themselves to be better than other individuals, and view the ingroup as superior to outgroups. This may be partly due to the fact that people are less likely to accept negative information about the individual self (e.g. Ditto \& Lopez, 1992; Kunda, 1990) or social self (e.g. Doosje et al., 1998; Norvell, \& Forsyth, 1984) than positive information. These mechanisms may help to interpret our results. When people are confronted with negative information about their group, they are likely to dissociate themselves from that group if possible. Low family involvement makes such an escape possible: 'Dutch people may have mistreated Indonesians in the past, but my family, and I myself, were not implicated'. However, when family involvement is high, there is no such possible 'exit' available. It is under these conditions that people have to accept the fact that their family, and thus their social self, has been part of a negative past. This results in negative self-conscious group-based emotions such as shame, and a relatively negative selfesteem derived from the family.

This is in line with the idea that people for whom their group is important, stick to the group through thick and thin (e.g. Doosje, Ellemers, \& Spears, 1995). Similarly, Wann, Hamlet, Wilson, and Hodges (1995) have shown that people find it more difficult to cut off reflected failure to the extent that they identify with their group.

Study 1 and Study 2 differ in terms of weaknesses and strengths. In Study 1, we focused on a naturally occurring situation (people sitting behind a computer looking at an actually existing website), and as such this study has a high external validity. However, the first study also has limitations: large cell differences in terms of number of participants, relatively simple dependent variables and a low internal validity due to the non-experimental nature of the family involvement variable. In Study 2, however, we remedied these weaknesses by manipulating family involvement (and thus deal with cell differences in $n$ s, and the internal validity issue) and using a larger number of items to assess the key dependent variables. Taken together, the two studies make a strong case for our arguments based on internal and external validity concerns.

In general, our studies offer support for Smith and Mackie's intergroup emotion theory. In our studies, we observe that people can experience specific emotions such as pride and shame in a group context, even when they were not implicated personally themselves. Importantly, by doing so, we focused on a new and understudied group: the family. Whereas previous studies in this domain primarily have focused on laboratory-created groups or national groups, we think it is important to include the family as an important group in studies on group-based emotion. Why is this important? First, almost everyone belongs to a family, and as such it is a very common group membership. Second, family may be a special sort of group, for example because of frequent interaction between members, thereby often creating a highly interdependent group structure, and the (unstable) status differences between parents and children. We think theories about groupbased emotions may benefit from including these different kinds of groups in order to achieve a general theory that is as broadly applicable as possible.

\section{Notes}

1. The predicted three-way interaction effect in Study 1 was considerably stronger when shame was used as the single indicator of negative selfconscious emotions $(F(1,146)=9.03, p=.003$, $\left.\eta^{2}=.027\right)$, and considerably weaker when guilt was used as a single indicator $(F(1,146)<1)$.

2. In Study 2, we also considered the influence of the distinctiveness (Brewer, 1991) of having a family involvement in the past. We explored the possibility that when people include the nation's colonization past in the self because of family involvement, people may prefer to share the glory with few (i.e. smaller groups) while they prefer to share the gloomy aspects with as many people as possible (i.e. bigger groups). Orthogonal to the manipulation of family involvement, we manipulated group distinctiveness in Study 2 by stating that nowadays, actually very few versus many people descended from those working for the VOC. This manipulation however did not 
influence participants' responses. That is, the results reported here are identical when this manipulation is included or excluded in the analyses. Perhaps the influence of this manipulation would have been stronger when it related more specifically to the distinctiveness of one's family vis-a-vis other families in terms of involvement, instead of to the involvement of the more general and abstract group of current descendants. These considerations and the exploratory purpose of this manipulation led us to exclude this factor from the analyses.

3. Additional analyses indicated that the pattern of results among the separate positive selfconscious emotion items were highly similar, as well as the pattern of results among the negative self-conscious emotion items.

4. We conducted regression analyses to examine whether the observed 'boost' in participants' family esteem from the negative to the positive high family involvement condition mediated the increase in positive and decrease in negative self-conscious emotions. In the high family involvement condition, participants' family esteem was significantly related to participants' self-conscious emotions, such that a higher esteem was associated with stronger positive and weaker negative self-conscious emotions. Consistent with our arguments, no such relation emerged in the low family involvement condition. However, participants' family esteem did not significantly mediate the observed pattern of results on the self-conscious emotions in the high family involvement condition.

\section{References}

Barkan, E. (2000). The guilt of nations: Restitution and negotiating historical injustices. New York: Norton.

Bar-On, D. (1990). Children of perpetrators of the Holocaust: Working through one's own moral self. Psychiatry, 53, 229-245.

Baumeister, R. F., \& Leary, M. R. (1995). The need to belong: Desire for interpersonal attachments as a fundamental human motivation. Psychological Bulletin, 117, 497-529.

Branscombe, N. R., Doosje, B., \& McGarty, C. (2002). Antecedents and consequences of collective guilt. In D. M. Mackie \& E. Smith (Eds.), From prejudice to intergroup emotions: Differentiated reactions to social groups (pp. 49-66). New York: Psychology Press.
Brewer, M. B. (1991). The social self: On being the same and different at the same time. Personality and Social Psychology Bulletin, 17, 475-482.

Cialdini, R. B., Borden, R. J., Thorne, A., Walker, M. R., Freeman, S., \& Sloan, L. R. (1976). Basking in reflected glory: Three (football) field studies. Journal of Personality and Social Psychology, 34, 366-375.

Crocker, J., \& Luhtanen, R. (1990). Collective selfesteem and ingroup bias. Journal of personality and Social Psychology, 58, 60-67.

Danieli, Y. (Ed.) (1998). International handbook of multigenerational legacies of trauma. New York: Plenum.

Ditto, P. H., \& Lopez, D. F. (1992). Motivated skepticism: Use of differential decision criteria for preferred and nonpreferred conclusions. Journal of Personality and Social Psychology, 63, 568-584.

Doosje, B., Branscombe, N. R., Spears, R., \& Manstead, A. S. R. (1998). Guilty by association: When one's group has a negative history. Journal of Personality and Social Psychology, 75, 872-886.

Doosje, B., Ellemers, N., \& Spears, R. (1995). Perceived intragroup variability as a function of group status and identification. Journal of Experimental Social Psychology, 31, 410-436.

Dumont, M., Yzerbyt, V., Wigboldus, D., \& Gordijn, E. (2003). Social categorization and fear reactions to the September $11^{\text {th }}$ terrorist attacks. Personality and Social Psychology Bulletin, 29, 1509-1520.

Ellemers, N. (1993). The influence of sociostructural variables on identity enhancement strategy. European Review of Social Psychology, 4, 27-57.

Gordijn, E. H., Wigboldus, D., \& Yzerbyt, V. (2001). Emotional consequences of categorizing victims of negative outgroup behavior as ingroup or outgroup. Group Processes $\mathcal{E}$ Intergroup Relations, 4, 317-326.

Kunda, Z. (1990). The case for motivated reasoning. Psychological Bulletin, 108, 480-498.

Lewis, M. (2000). Self-conscious emotions: Embarrassment, pride, shame, and guilt. In M. Lewis \& J. M. Haviland-Jones (Eds.), Handbook of emotions (pp. 623-636). New York: Guilford.

Lickel, B., Schmader, T., Curtis, M., Scarnier, M., \& Ames, D. R. (2005). Vicarious shame and guilt. Group processes $\mathcal{E}$ Intergroup Relations, 8, 145-157.

Luhtanen, R., \& Crocker, J. (1992). A collective self-esteem scale: Self-evaluation of one's social identity. Personality and Social Psychology Bulletin, 18, 302-318. 
Mackie, D. M., Devos, T., \& Smith, E. R. (2000). Intergroup emotions: Explaining offensive action tendencies in an intergroup context. Journal of Personality and Social Psychology, 79, 602-616.

Mackie, D. M., \& Smith, E. R. (Eds.). (2002). From prejudice to intergroup emotions: Differentiated reactions to social groups. New York: Psychology Press.

Mullen, B., Migdal, M. J., \& Rozell, D. (2003). Selfawareness, deindividuation, and social identity: Unraveling theoretical paradoxes by filling empirical lacunae. Personality and Social Psychology Bulletin, 29, 1071-1081.

Norvell, N., \& Forsyth, D. R. (1984). The impact of inhibiting or facilitating causal factors on group members' reactions after success and failure. Social Psychology Quarterly, 47, 293-297.

Pennekamp, S. F., Doosje, B., Zebel, S., \& Fischer, A. H. (2007). The past and the pending: The antecedents and consequences of group-based anger in historically and currently disadvantaged groups. Group Processes $\mathcal{E}$ Intergroup Relations, 10, 41-55.

Scherer, K. R., Schorr, A., \& Johnstone, T. (Eds.). (2001). Appraisal processes in emotion: Theory, methods, research. New York: Oxford University Press.

Smith, E. R. (1993). Social identity and social emotions: Toward new conceptualizations of prejudice. In M. D. Mackie \& D. L. Lewis (Eds.), Affect, cognition, and stereotyping: Interactive processes in group perception (pp. 297-315). San Diego, CA: Academic Press.

Snyder, C. R., Lassegard, M., \& Ford, C. E. (1986). Distancing after group success and failure: Basking in reflected glory and cutting off reflected failure. Journal of Personality and Social Psychology, 51, 382-388.

Swim, J. K., \& Miller, D. L. (1999). White guilt: Its antecedents and consequences for attitudes toward affirmative action. Personality and Social Psychology Bulletin, 25, 500-514.

Tabachnick, B. G., \& Fidell, L. S. (2001). Using Multivariate statistics. London: Allyn and Bacon.

Tajfel, H. (1978). Social categorization, social identity and social comparison. In H. Tajfel (Ed.), Differentiation between social groups: Studies in the social psychology of intergroup relations (pp. 61-76). London: Academic Press.

Tajfel, H., \& Turner, J. C. (1979). An integrative theory of intergroup conflict. In W. G. Austin \& S. Worchel (Eds.), The social psychology of intergroup relations (pp. 33-48). Monterey, CA: Brooks-Cole.
Tajfel, H., \& Turner, J. C. (1986). The social identity theory of intergroup conflict. In S. Worchel \& W. G. Austin (Eds.), Psychology of intergroup relations (pp. 7-24). Chicago: NelsonHall.

Tangney, J. P., \& Dearing, R. L. (2002). Shame and guilt. New York: Guilford.

Tracy, J. L., \& Robins, R. W. (2004). Putting the self into self-conscious emotions: A theoretical model. Psychological Inquiry, 15, 103-125.

Wann, D. L., Hamlet, M. A., Wilson, T. M., \& Hodges, J. A. (1995). Basking in reflected glory, cutting off reflected failure, and cutting off future failure: The importance of group identification. Social Behavior and Personality, 23, 377-388.

Wolf, M. (2005). Srebrenica 10 jaar later: De Nederlander en Srebrenica [Srebrenica: 10 years later: The Dutch and Srebrenica]. http://www.ikonrtv.nl/uploadedDocs/ enquete_srebrenica.pdf. Retrieved on December 1, 2005.

Yzerbyt, V., Dumont, M., Wigboldus, D., \& Gordijn, E. (2003). I feel for us: The impact of categorization and identification on emotions and action tendencies. British Journal of Social Psychology, 42, 533-549.

Paper received 1 December 2005; revised version accepted 18 July 2006.

\section{Biographical notes}

SVEN ZEBEL is a post-doc in social psychology at the University of Amsterdam. His research interests include perpetrator-victim intergroup relations, group-based and collective emotions, intra- and intergroup insults, and components of group identification.

SJOERD F. PENNEKAMP is a graduate student in social psychology at the University of Amsterdam. His research interests concern intergroup behavior in general, and intergroup emotions, intergroup communication and identification processes in particular.

MARTIJN VAN ZOMEREN is an assistant professor at the Free University at Amsterdam. His research interests revolve around the influence of specific emotions on intra- and intergroup processes and behavior in the domains of collective action, social identity, emotion, morality, and social influence. 
BERTJAN DOOSJE is an associate professor in social psychology at the University of Amsterdam. He does research on emotions in intergroup relations, psychological consequences of terrorism, and on partner preferences.

GERBEN A. VAN KLEEF is an assistant professor in social psychology at the University of Amsterdam. His two main streams of research focus on: (1) the interpersonal effects of emotions in a variety of contexts, such as conflict, negotiation, and leadership; and (2) motivational processes in intergroup relations.
MICHAEL L. W. VLIEK is an assistant professor in social psychology at the University of Amsterdam. His main research interests include social comparison and the dynamics of self-evaluation, intra-group processes and achievement motivation.

JOB VAN DER SCHALK is a graduate student in social psychology at the University of Amsterdam. His main research involves emotional contagion in intergroup contexts. Additionally, he is interested in the functionality of heuristics in negotiation. 